УДК 347.78

https://doi.org/10.34142/23121661.2021.33.08

orcid.org/0000-0001-7917-9856

(C) Прийменко О.С., 2021

О.С. ПРИЙМЕНКО

\title{
ДЕЯКІ ПИТАННЯ ВІЛЬНОГО ВИКОРИСТАННЯ ТВОРІВ БЕЗ ЗГОДИ АВТОРА (НА ПРИКЛАДІ СУДОВИХ СПРАВ)
}

\section{O. PRYIMENKO}

\section{SOME ISSUES OF FREE USE OF WORKS WITHOUT THE AUTHOR'S CONSENT (ON THE EXAMPLE OF COURT CASES)}

\begin{abstract}
Анотація. Метою статті $є$ вивчення дозволених меж вільного використання творів із зазначенням імені автора і джерела запозичення з огляду на поставлену мету відповідно до судової практики. У роботі зазначено, що питання використання коротких уривків з опублікованих творів, а також використання творів як ілюстрацій у виданнях навчального типу отримало належну увагу з боку вчених, але й досі залишається дискусійним. Проаналізовано судові справи 3 цих питань. У статті запропоновано під час правозастосування у випадку сумнівів надавати пріоритет правам авторів творів та враховувати загальні засади цивільного законодавства, тому що невиправданість дій поставленій меті може породжувати судові суперечки.
\end{abstract}

Ключові слова: вільне використання твору, короткий уривок, цитата, судова практика, автор.

Аннотация. Целью статьи является изучение разрешенных пределов свободного использования произведений с указанием имени автора и источника заимствования с учетом поставленной цели в соответствии с судебной практикой. Отмечается, что вопросы использования коротких отрывков из опубликованных произведений, а также использования самих произведений в качестве иллюстраций в изданиях учебного типа получили должное внимание со стороны ученых, но до сих пор остаются дискуссионными. Проанализированы судебные дела по этим вопросам. В статье предложено во время правоприменения в случае сомнений отдавать приоритет правам авторов произведений и учитывать общие принципы гражданского законодательства, так как неоправданность действий поставленной цели может порождать судебные споры.

Ключевые слова: свободное использование произведения, короткий отрывок, цитата, судебная практика, автор.

Abstract. The purpose of the article is to study the permitted limits for the free use of works, indicating the name of the author and the source of borrowing, taking into account the set 
goal under judicial practice. It is noted that the issues of using short excerpts from published works, as well as the use of works as illustrations in educational publications, havereceived due attention from scholars, but remains controversial. For example, the legality of using quotations in practice creates many problems for the subjects. Three court cases have been analyzed. Each of them reveals the specifics of the lawful use of various types of works, taking into account the specific actions of the subjects. The first case is interesting for higher education institutions. The court made a rather controversial conclusion about the factual admissibility of a small amount of plagiarism in the student's work. The second case concerned the inadmissibility of the free use of a drawing in the educational literature to increase the sales of such publication. Thus, the admissibility of using the work as an illustration was not justified. The third case allows once again emphasizing the great importance of the conclusions of the forensic examination in this category of court cases. In the article, it is proposed to give priority to the rights of authors of works during law enforcement in case of doubts. The use of works without the permission of the author must have a clear, understandable explanation. The principles of civil law (good faith and reasonableness) should also be taken into account since the unjustified actions of the set goal can give rise to litigation.

Key words: free use of the work, short excerpt, quotation, case law, author.

Постановка проблеми. Питання вільного використання творів із зазначенням імені автора та джерела запозичення обговорюється в юридичній науці вже давно, але й досі немає єдності, наприклад, в розумінні того, в який спосіб чітко визначати обсяг короткого уривка (цитати) та наскільки це було виправдано поставленою метою. Проблема ускладнюється тим, що використання коротких уривків - це необхідність та поширене явище серед суб'єктів, які не є фахівцями в галузі права, зокрема серед освітянської спільноти, митців тощо. Без цитування досягнень попередників важко уявити рух вперед як наукової, так і мистецької діяльності. Не менше питань виникає під час використання літературних і художніх творів як ілюстрацій у виданнях, передачах мовлення, звуко- чи відеозаписах навчального типу.

Аналіз останніх досліджень. Порядок вільного використання творів обговорювався в роботах І. Зайцевої-Калаур, Ю. Капіци, В. Троцької, К. Шахбазян та інших науковців. Зазначені автори розглядали особливості вільного використання творів у засобах масової інформації, у видавничому процесі або 3 метою забезпечення громадського порядку. Однак недостатньо вивченою залишається судова практика щодо використання коротких уривків з різноманітних видів творів або творів як ілюстрацій у виданнях навчального типу. Отже, потрібно й надалі продовжувати наукові пошуки у сфері вільного використання творів без згоди автора (чи іншої особи, яка має авторське право).

Формулювання мети статті (постановка завдання). Відповідно до актуальності досліджуваної теми метою статті $\epsilon$ аналіз дозволених меж вільного використання творів із зазначенням імені автора та джерела запозичення 3 
огляду на поставлену мету такого використання відповідно до української судової практики.

Виклад основного матеріалу. Вільне використання творів $є$ прикладом пошуку балансу між публічними та приватними інтересами [1, с. 32]. У ст. 444 Цивільного кодексу України (далі - ЦК України) та ст. 21 Закону України «Про авторське право і суміжні права» (далі - Закон) визначено вичерпний перелік дозволених випадків вільного використання творів [2; 3].

У ст. 1 Закону визначено, що цитата - це «порівняно короткий уривок 3 літературного, наукового чи будь-якого іншого опублікованого твору, який використовується $з$ обов'язковим посиланням на його автора і джерела цитування іншою особою у своєму творі з метою зробити більш зрозумілими свої твердження або для посилання на погляди іншого автора в автентичному формулюванні» [3]. Вимога до виправданості обсягу цитування, відтворення творів 3 огляду на мету міститься в пунктах 1, 2, 4, 7, 8, 9 ст. 21 Закону і в ст. 10 Бернської конвенції про охорону літературних і художніх творів [3; 4].

Тонку межу між порушенням авторського права та вільним використанням твору проаналізуємо на прикладі трьох судових справ. Кожна 3 них визначає специфіку правомірного використання різноманітних видів творів 3 огляду на конкретні дії суб’єктів.

Так, рішення Апеляційного суду міста Києва від 17 червня 2016 р. щодо справи № 758/1464/15-ц окреслює проблемні питання, з якими стикаються здобувачі вищої освіти та заклади вищої освіти під час встановлення факту плагіату [5].

До Національного університету «Києво-Могилянська академія» (далі Університет) звернулася особа з позовом про визнання наказу про іiі відрахування недійсним та зобов'язання вчинити певні дії. Позивачка здобувала освітньо-кваліфікаційний рівень спеціаліста за напрямом правничі науки. У зв’язку з виявленим плагіатом державна екзаменаційна комісія (далі - ДЕК) Університету оцінила їі кваліфікаційну роботу як «незадовільну». Відповідно до рішення ДЕК Університету особа була відрахована зі складу студентів. На думку позивачки, відповідачем не були фактично оцінені іï знання, а в роботі відсутній плагіат.

Призначена судова експертиза встановила часткове відтворення фрагментів творів без відповідного посилання (три фрагменти).У зазначених фрагментах були наявні ознаки плагіату. Однак це не вплинуло на висновок експерта, що кваліфікаційна робота позивачки є результатом творчої праці.

Під час розгляду справи підтвердився лише один із визначених в протоколі ДЕК фрагментів. На думку суду, це не є достатнім для позбавлення студента диплома та/або анулювання його роботи загалом. Суд не прийняв до 
уваги інші фрагменти, оскільки вони не були зазначені як підстави Комісією 3 виявлення плагіату та не були предметом розгляду ДЕК.

Суд зазначив, що комісія обмежилась обговоренням окремих фактів плагіату, а не кваліфікаційної роботи загалом. 3 огляду на обсяг та тип виявлених під час дослідження текстуальних збігів із фрагментами робіт інших авторів, на думку експерта, не можна ставити під сумнів самостійність та творчий тип виконаної роботи позивачки. Також суд визначив цілу низку процедурних порушень 3 боку відповідача, зокрема процедури допуску до захисту. Таким чином, наказ Університету про відрахування особи через невиконання навчального плану було визнано незаконним [5].

Аналіз рішення суду підтверджує наявність порушень з боку Університету, а саме локального положення про запобігання плагіату та запровадження практики належного цитування під час навчального процесу, в якому визначено іншу послідовність дій, ніж та, що була реалізована щодо кваліфікаційної роботи позивачки. Проте дискусійним є висновок про фактичну допустимість невеликого обсягу плагіату в роботі студента. Як слушно зауважує С. Ніколаєв, фіксація допустимого відсотка текстових збігів $є$ хибною практикою [6], а перший етап контролю повинен здійснювати автор [7, с. 60].

Крім того, це стає дивним з точки зору постійного пропагування Міністерством освіти і науки України, Національним агентством із забезпечення якості вищої освіти та неурядовими організаціями значення академічної доброчесності в підвищенні якості освітнього процесу. I хоча поняття академічної доброчесності нещодавно увійшло до нормативного обігу, але вже стало предметом активної дискусії.

Отже, з одного боку, необхідність суворого дотримання педагогічними, науково-педагогічними i науковими працівниками норм законодавства про авторське право і суміжні права визначена в контексті академічної доброчесності, а з іншого боку, такий судовий прецедент може відкрити шлях до того, що заклади вищої освіти просто не будуть застосовувати будь-які суттєві санкції за порушення вимог академічної доброчесності, побоюючись оскарження своїх дій.

Водночас згадане рішення суду має спонукати до розроблення чітких положень щодо притягнення здобувачів вищої освіти до відповідальності та до уважного вивчення уповноваженим науково-педагогічним працівником (комісією) кожної письмової роботи. Також повністю підтримуємо позицію, відповідно до якої «аналіз тексту на ознаки можливого академічного плагіату передбачає, що кожен текстовий збіг, виявлений програмою, обов'язково має аналізувати людина» [6].

Порушення майнових прав під час використання творів образотворчого мистецтва в підручнику для навчальних закладів досліджувалося в Постанові 
Верховного Суду України від 23 січня 2018 року у справі № 569/11789/15-ц [8]. Позивачі (співвласники виключних майнових прав на художній твір «Рудоволоса дівчина» звернулися до суду 3 метою поновлення авторських прав, стягнення компенсації у зв'язку з розміщенням малюнка на палітурці підручника «Образотворче мистецтво. 3 клас» для загальноосвітніх навчальних закладів. Дозвіл на використання твору відповідачам не надавався.

У касаційній скарзі одним із доводів відповідача був той факт, що художній твір було використано у навчальному виданні. Цей аргумент суд не взяв до уваги, адже не доведено використання суперечливого художнього твору в обсязі, виправданому поставленою метою, як ілюстрацій у навчальних виданнях, що підтверджено й висновком судової експертизи об’єктів інтелектуальної власності. Крім того, твір було використано з комерційною метою [8].

Погоджуючись 3 правовою оцінкою суду, необхідно зазначити, що видання саме навчальної літератури не формує правовий режим вільного використання творів для видавців. У п. 2 ч. 1 ст. 21 Закону міститься положення, що в таких виданнях використання літературних і художніх творів $є$ допустимим як ілюстрацій та в обсязі, виправданому поставленою метою. Обов'язково за такої умови необхідно дотримуватися звичаїв. Вимога, обумовлена ст. 10 Бернської конвенції про охорону літературних і художніх творів, визначає «відповідати як встановленій практиці, так і розумінню сумлінного використання для кожного з можливих випадків» [9, с. 52].

Крім того, необхідно дотримуватись загальних засад цивільного законодавства, викладених у ст. 3 ЦК України [2], зокрема про добросовісність [10] і розумність. У випадку наявності дій, спрямованих на порушення права інтелектуальної власності, «цивільне право спрямоване на підтримання і відновлення справедливого балансу прав і інтересів його учасників, які порушено зазначеними недобросовісними й нерозумними діями» [11, с. 113].

Отже, використання творів без дозволу автора повинно мати чітке зрозуміле пояснення, а у випадку сумнівів щодо доцільності таких дій, необхідно надавати пріоритет правам автора твору. На нашу думку, розміщення малюнка на палітурці безпосередньо не забезпечує досягнення навчальної мети, а слугує лише покращенню товарного вигляду друкованої продукції. Відповідач повинен був отримати дозвіл від співвласників виключних майнових прав на художній твір.

Допустимість цитування літературного твору досліджувалася в Постанові Рівненського апеляційного суду від 20 лютого 2020 року у справі № 559/32/17 [12]. На офіційному сайті авторів ART of WAR позивач розмістив свій роман. За сприяння Дубенської міської ради було випущено літературно-публіцистичне видання, в якому опубліковано уривок з роману позивача без мети отримання прибутку. Відповідачі використали фрагмент зазначеного роману як 
цитату, основний акцент було зроблено на розповіді про воїна-інтернаціоналіста.

Як було визначено судом, позивач не спростував, що опубліковані у виданні уривки його роману не є цитатами. Крім того, позивач не заявляв клопотання про призначення відповідної експертизи. Відповідачами були дотримані вимоги законодавства щодо зазначення імені автора і джерела запозичення. Отже, «у цьому випадку мало місце використання твору як цитат (коротких уривків) з нього в обсязі, виправданому зазначеною метою (тобто більш повного інформування читачів про творчість відповідного автора), із зазначенням у списку використаних джерел імені автора і джерела запозичення» [12].

Загалом погоджуючись 3 позицією суду, необхідно викласти власні міркування з окремих питань: по-перше, у справах, пов'язаних із забезпеченням дотримання авторського права важливу функцію, на нашу думку, здійснює експертиза. Так, у цьому випадку іiі відсутність могла стати одним із вирішальних факторів на користь відповідача; по-друге, ні суд першої інстанції, ні апеляційний суд не зазначили обсяг процитованого відповідачами уривка, зокрема, як порівняти із загальним обсягом роману позивача. Відомо, що українським законодавством не визначено допустимого обсягу, проте визначення обсягу процитованого матеріалу сприяло б аргументованості рішення; потретє, суд врахував, що видання розповсюджувалося на безоплатній основі і не містило комерційної складової. На нашу думку, зазначена обставина не може впливати на оцінку дій відповідача, тому що в Законі немає залежності між правомірним використанням коротких уривків твору та комерційною/некомерційною метою. Отже, необхідно обов'язково визначати поставлену мету. I суд це зробив, зазначивши «більш повне інформування читачів про творчість відповідного автора» [12]. Проте таке визначення не може автоматично використовуватися іншими авторами для пояснення своєї мети без детального обгрунтування конкретними обставинами справи, адже воно $є$ доволі узагальненим і розмитим.

Висновки 3 цього дослідження й перспективи подальших розвідок у цьому напрямі. Отже, оскільки використання цитат створює багато проблем, вивчення судової практики стає корисним дороговказом. Кожна із розглянутих судових справ є орієнтиром для правозастосовувачів щодо оцінки правомірності дій, коли здійснюється аналіз використання коротких уривків з різноманітних видів творів або творів як ілюстрацій у навчальних виданнях.

Необхідно враховувати насамперед вимоги ЦК України, Закону України «Про авторське право і суміжні права», Бернської конвенції про охорону літературних і художніх творів щодо посилання на автора і джерело. Але, як демонструє судова практика, одним з визначальних моментів у встановленні правомірності поведінки суб'єктів може стати вивчення дій відповідачів 3 
погляду поставленої ними під час використання твору мети. Останню доволі важко визначити без звернення до таких загальних засад цивільного законодавства як добросовісність і розумність. Крім того, необхідно звертати увагу на важливе значення проведення судової експертизи.

Таким чином, особи, які використовують короткі уривки (цитати) 3 опублікованих творів або літературні та художні твори як ілюстрації у виданнях, мають бути дуже уважними і зважати на можливі ризики судових позовів до них щодо порушень авторських прав.

\section{Література}

1. Троцька В. М. Вільне використання творів з метою забезпечення функціонування державного механізму. Теорія і практика інтелектуальної власності. 2016. Вип. 1. С. 32-41; 2. Цивільний кодекс України від 16січня 2003 p. № 435-IV. URL: https://zakon.rada.gov. ua/ laws/show/435-15; 3. Про авторське право і суміжні права: Закон України від 23 грудня 1993 p. № 3792-XII. URL: https://zakon.rada.gov.ua/laws/show/3792-12; 4. Бернська конвенція про охорону літературних і художніх творів від 24 липня 1971 p. URL: https://zakon.rada. gov.ua/laws/show/995_051; 5. Рішення Апеляційного суду міста Києва від 17 червня 2016 р. у справі № 758/1464/15-ц: Єдиний державний реєстр судових рішень. URL: https://reyestr.court. gov.ua/Review/58674725; 6. Ніколаєв Є. Академічна доброчесність. Інформаційний бюлетень. 2019. Вип. 4. URL: https://skeptic.in.ua/wp-content/uploads/Integrity-bulletin-04.pdf; 7. Капіца Ю.М. Видавничий процес і авторське право. Наука України у світовому інформаційному просторі. 2019. Вип. 16. С. 59-73. https://doi.org/10.15407/akademperiodyka.391.059; 8. Постанова Верховного Суду України від 23січня 2018 р. у справі № 569/11789/15-ц: Єдиний державний реєстр судових рішень. URL: https://reyestr.court.gov.ua/Review/71897142; 9. Шахбазян К. С. Застосування в наукових публікаціях цитат із опублікованих творів, права на які належать іншим авторам. Наука України у світовому інформаційному просторі. 2017. Вип. 14. С. 51-58. https://doi.org/10.15407/akademperiodyka.337.051; 10. Зайцева-Калаур I. В. Межі використання авторських творів журналістів організаціями ЗМІ. Часопис Академії адвокатури України. 2013. № 3. URL: http://nbuv.gov.ua/UJRN/Chaau_2013_3_10; 11. Тобота Ю. А. Принцип справедливості, добросовісності і розумності в цивільному праві: монографія. Харків: ХНПУ, 2020. 140 с. 12.Постанова Рівненського апеляційного суду від 20 лютого 2020 р. у справі № 559/32/17: Сдиний державний реєстр судових рішень. URL: https://reyestr.court.gov.ua/Review/87756145. 